\title{
3-Methylhistidine excretion as an index of myofibrillar protein catabolism in neuromuscular disease
}

\author{
R. O. M c KER A N, D. H A L L I D A Y,P.PURK IS S, \\ A N D P. ROYSTON \\ From the Medical Research Council, Clinical Research Centre, Harrow \\ and University College Hospital, London
}

SUMMARY Myofibrillar protein catabolism has been calculated in a variety of neuromuscular diseases from the amount of 3-methylhistidine excreted in the urine. It was found to be significantly raised in Duchenne type muscular dystrophy, motor neurone disease, polymyositis, and thyrotoxic myopathy. In Becker type muscular dystrophy the level was slightly raised. It was normal in scapuloperoneal and limb girdle dystrophy, dystrophia myotonica, extrapyramidal disease, and multiple sclerosis. It was significantly decreased in hypothyroid myopathy.

Increased levels of serum creatine phosphokinase (CPK, adenosine $5^{\prime}$ triphosphate-creatine phosphotransferase, EC 2.7.3.2) have been of great value in the diagnosis of the affected hemizygote and heterozygote in Duchenne type muscular dystrophy, in distinguishing spinal muscular atrophy from similar clinical phenotypes with a primary myopathic aetiology, and in confirming the diagnosis of polymyositis. They have also been of use in following the response to treatment in polymyositis and hypothyroid myopathy. However, although it is often assumed that CPK levels may be taken as an index of muscle cell dysfunction, and relate to the degree of abnormality in muscle metabolism, they do not bear a close relationship to muscle cell pathology under all circumstances. In a recent study of hypothyroid myopathy, raised central nuclear counts and a type 2 muscle fibre atrophy and loss bore a much closer relationship to clinical improvement in a proximal myopathy with L-thyroxine treatment than elevated levels of CPK (McKeran et al., 1979). Similarly, in polymyositis serum CPK values may be normal after the introduction of steroids when there is still marked clinical weakness. These observations indicate the need to develop other in vivo para-

Address for reprint requests: Dr R. O. McKeran, Division of Inherited Metabolic Diseases, Clinical Research Centre, Watford Road, Harrow HA1 3UJ, Middlesex.

Accepted 28 November 1978 meters to assess abnormal muscle biochemistry. This is of particular importance if the response 2 to possible treatment regimes is to be studied, since truly objective tests of muscle strength are not always available. As part of such an approach, the estimation of muscle myofibrillar protein catabolic rate from 3-methylhistidine excretion in urine has been made in patients with a variety of neuromuscular diseases while on a normal diet and compared with appropriate age- and sex-matched control values. Further patients with different types of muscular dystrophy were studied on a creatine-free diet, to eliminate the fluctuating dietary component of 3-methylhistidine excretion, and compared with control values.

\section{Patients and methods}

Three consecutive 24 hour urine samples were obtained from patients with a wide variety of neuromuscular disorders while on a normal diet with no additional vitamin or drug therapy (Table 1). Ageand sex-matched normal volunteers served as control subjects. Additional patients with a variety of muscular dystrophies were studied while on a standard creatine-free diet for up to seven days with complete 24 hour urine collections (Table 2). Myofibrillar protein catabolic rate was calculated from the mean value of 3-methylhistidine excretion from day 4 to day 7 . The creatine-free diet contained $40 \mathrm{~g}$ of protein $/ \mathrm{m}^{2}$ and $5 \mathrm{MJ} / \mathrm{m}^{2}$ body 
surface area. Five healthy male volunteers on a creatine-free diet served as control subjects.

Urinary 3-methylhistidine was measured by means of a Technicon TSM amino-acid analyser. The standard physiological fluid analysis cycle was curtailed so that only the basic amino-acids were measured. L-canavanine was used as an internal standard. Urinary creatinine was measured by the method of Edwards and Whyte (1958).

\section{CALCULATION}

Muscle myofibrillar protein catabolic rate was calculated from:

3-Methylhistidine excretion ( $\mu$ moles $/ 24 \mathrm{~h}) / 6.46 \mathrm{~g}$. of myofibrillar protein/day.

Assuming the concentration of 3-methylhistidine in mixed proteins of human muscles is $4.2 \mu$ moles/ g mixed protein (Bilmazes et al., 1978), and that myofibrillar protein constitutes $65 \%$ of total muscle protein. The percentage turnover per day of myofibrillar protein was calculated from the following formula:

Myofibrillar protein catabolic rate

Total muscle myofibrillar protein

Assuming $1 \mathrm{~g}$ of creatinine excreted is equivalent to $20 \mathrm{~kg}$ of muscle (Graystone, 1968), creatinine excretion is a measure of lean body mass in muscle diseases (Ryan et al., 1957), and protein constitutes $20 \%$ of muscle mass of which $65 \%$ is myofibrillar protein.

\section{Results}

The values for creatinine excretion, 3-methylhistidine excretion, muscle mass, total muscle myofibrillar protein, myofibrillar protein catabolism, and myofibrillar protein catabolic rate $( \pm 1 \mathrm{SD})$ in the varieties of neuromuscular disease studied are shown in Tables 1 and 2 together with the appropriate control values ( $\pm 1 \mathrm{SD})$. Apart from Duchenne muscular dystrophy, the other varieties of dystrophy were studied while on a creatine-free diet, since it was felt that smaller increases in myofibrillar protein catabolism might be detected in these disorders by eliminating the fluctuating dietary component to 3-methylhistidine excretion. This was confirmed by comparing within-subject standard deviations in control and patient groups on a diet and not on a diet. The amount of variation was significantly decreased in the combined control and patient groups when on a creatine-free diet $(P<0.02)$. The dietary contribution to 3methylhistidine excretion significantly increased the myofibrillar protein catabolic rate when male control values on and not on a diet were compared $(P<0.05)$. Some evidence of skewness and heteroscedasticity in the myofibrillar protein catabolic rates was removed by logarithmic transformation. A pooled variance for each group (male not on a diet, female not on a diet, and male on a creatine-free diet) was calculated, and individual

Table 1 Myofibrillar protein catabolic rates in groups of patients with neuromuscular disease contrasted with control values, all subjects on a normal diet

\begin{tabular}{|c|c|c|c|c|c|c|c|}
\hline 1 & 2 & 3 & 4 & 5 & 6 & 7 & 8 \\
\hline Clinical diagnosis & $\begin{array}{l}\text { Mean }(S D) \\
\text { creatinine } \\
\text { excretion } \\
\left(g \text { day }{ }^{-1}\right)\end{array}$ & $\begin{array}{l}\text { Mean }(S D) 3- \\
\text { methylhistidine } \\
\text { excretion } \\
\left(\mu m o l \text { day }{ }^{-1}\right)\end{array}$ & $\begin{array}{l}\text { Mean } \\
\text { muscle } \\
\text { mass }(k g)\end{array}$ & $\begin{array}{l}\text { Mean } \\
\text { muscle } \\
\text { myofibrillar } \\
\text { protein }(\mathrm{kg})\end{array}$ & $\begin{array}{l}\text { Mean } \\
\text { myofibrillar } \\
\text { protein } \\
\text { catabolism } \\
\left(g \text { day }^{-1}\right)\end{array}$ & $\begin{array}{l}\text { Mean }(S D) \\
\text { fractional } \\
\text { myofibrillar } \\
\text { protein } \\
\text { catabolic rate } \\
\left(\% \text { day }^{-1}\right)\end{array}$ & $\begin{array}{l}\text { Significance } \\
\text { level } P \\
(\text { using } t \text { test }) \\
(N S=P>0.1)\end{array}$ \\
\hline Derivation & & & $(2) \times 20$ & $\begin{array}{l}(4) \times 0.65 \times \\
0.20\end{array}$ & (3) $\times \frac{0.65}{4.2}$ & $\frac{(6)}{(5)} \times 0.1$ & \\
\hline $\begin{array}{l}\text { Duchenne muscular dystrophy } \\
\text { males }(n=7)\end{array}$ & $0.23(0.06)$ & $116(58)$ & 4.56 & 0.593 & 18.0 & $3.05(1.42)$ & $<0.001$ \\
\hline $\begin{array}{l}\text { Polymyositis } \\
\text { females }(n=2)\end{array}$ & $1.10(0.45)$ & $300(68)$ & 22.1 & 2.87 & 46.4 & $1.68(0.32)$ & $<0.05$ \\
\hline $\begin{array}{l}\text { Thyrotoxic myopathy } \\
\text { females }(n=6)\end{array}$ & $0.75(0.28)$ & $172(43)$ & 15.1 & 1.96 & 26.7 & $1.46(0.40)$ & $<0.05$ \\
\hline $\begin{array}{l}\text { Hypothyroid myopathy } \\
\text { females }(n=3) \\
\text { Multiple sclerosis }\end{array}$ & $1.25(0.12)$ & $140(18)$ & 25.0 & 3.25 & 21.6 & $0.68(0.15)$ & $<0.05$ \\
\hline $\begin{array}{l}\text { males }(n=4) \\
\text { females }(n=2)\end{array}$ & $\begin{array}{l}1.06(0.58) \\
0.95(0.05)\end{array}$ & $\begin{array}{l}178(101) \\
134(27)\end{array}$ & $\begin{array}{l}21.3 \\
19.0\end{array}$ & $\begin{array}{l}2.76 \\
2.47\end{array}$ & $\begin{array}{l}27.5 \\
20.7\end{array}$ & $\begin{array}{l}0.98(0.18) \\
0.83(0.13)\end{array}$ & $\begin{array}{l}\text { NS } \\
\text { NS }\end{array}$ \\
\hline $\begin{array}{l}\text { Motor neurone disease } \\
\text { females }(n=1) \\
\text { Parkinsonism }\end{array}$ & $0.76-$ & $251-$ & 15.2 & 1.98 & 38.8 & 1.96 & $<0.05$ \\
\hline $\begin{array}{l}\text { Parkınsonısm } \\
\text { females }(n=1) \\
\text { Lesch-Nyhan syndrome }\end{array}$ & $0.99-$ & $149-$ & 19.8 & 2.58 & 23.1 & 0.89 & NS \\
\hline $\begin{array}{l}\text { males }(n=2) \\
\text { Control subjects }\end{array}$ & $0.73(0.72)$ & $124(67)$ & 14.6 & 1.90 & 19.2 & $1.43(0.86)$ & NS \\
\hline $\begin{array}{l}\text { males }(n=11) \\
\text { females }(n=10)\end{array}$ & $\begin{array}{l}1.53(0.16) \\
1.19(0.11)\end{array}$ & $\begin{array}{l}283(53) \\
204(59)\end{array}$ & $\begin{array}{l}30.6 \\
23.9\end{array}$ & $\begin{array}{l}3.98 \\
3.10\end{array}$ & $\begin{array}{l}43.8 \\
31.5\end{array}$ & $\begin{array}{l}1.10(0.17) \\
1.03(0.33)\end{array}$ & \\
\hline
\end{tabular}


Table 2 Myofibrillar protein catabolic rates in groups of patients with neuromuscular disease contrasted with control values, all subjects on a creatine-free diet

\begin{tabular}{|c|c|c|c|c|c|c|c|}
\hline 1 & 2 & 3 & 4 & 5 & 6 & 7 & 8 \\
\hline Clinical diagnosis & $\begin{array}{l}\text { Mean }(S D) \\
\text { creatinine } \\
\text { excretion } \\
\left(g \text { day }{ }^{-1}\right)\end{array}$ & $\begin{array}{l}\text { Mean }(S D) \text { 3- } \\
\text { methylhistidine } \\
\text { excretion } \\
\left(\mu \text { mol day }^{-1}\right)\end{array}$ & $\begin{array}{l}\text { Mean } \\
\text { muscle } \\
\text { mass }(k g)\end{array}$ & $\begin{array}{l}\text { Mean } \\
\text { muscle } \\
\text { myofibrillar } \\
\text { protein }(\mathrm{kg})\end{array}$ & $\begin{array}{l}\text { Mean } \\
\text { myofibrillar } \\
\text { protein } \\
\text { catabolism } \\
\left(g_{\text {day }}^{-1}\right)\end{array}$ & $\begin{array}{l}\text { Mean }(S D) \\
\text { fractional } \\
\text { myofibrillar } \\
\text { protein } \\
\text { catabolic rate } \\
\left(\% \text { day }^{-1}\right)\end{array}$ & $\begin{array}{l}\text { Significance } \\
\text { level } P \\
(N S=P>0.1\end{array}$ \\
\hline $\begin{array}{l}\text { Becker muscular dystrophy } \\
\text { males }(n=2) \\
\text { Dystrophia myotonica }\end{array}$ & $0.50(0.00)$ & $102(12)$ & 10.1 & 1.31 & 15.8 & $1.21(0.15)$ & $<0.1$ \\
\hline $\begin{array}{l}\text { males }(n=2) \\
\text { females }(n=1)\end{array}$ & $\begin{array}{l}0.86(0.06) \\
0.59-\end{array}$ & $\begin{array}{l}151(17) \\
85-\end{array}$ & $\begin{array}{l}17.2 \\
11.8\end{array}$ & $\begin{array}{l}2.23 \\
1.54\end{array}$ & $\begin{array}{l}23.4 \\
13.2\end{array}$ & $\begin{array}{l}1.05(0.12) \\
0.86-\end{array}$ & NS \\
\hline $\begin{array}{l}\text { Limb girdle dystrophy } \\
\text { males }(n=1) \\
\text { Scapuloperoneal muscular dys }\end{array}$ & $\begin{array}{l}0.89- \\
\text { rophy }\end{array}$ & $112-$ & 17.7 & 2.31 & 17.3 & $0.75-$ & NS \\
\hline $\begin{array}{l}\text { males }(n=1) \\
\text { Control subjects }\end{array}$ & $\begin{array}{l}\text { rophy } \\
0.64-\end{array}$ & $88-$ & 12.7 & 1.65 & 13.6 & $0.82-$ & NS \\
\hline males $(n=5)$ & $1.56(0.28)$ & $224(36)$ & 31.2 & 4.06 & 34.7 & $0.87(0.17)$ & \\
\hline
\end{tabular}

*No significance level for the female dystrophia myotonica patient was calculated, as no female control subjects on a creatine-free diet were available.

disease group means were compared with their appropriate control group mean using Student's $t$ test (Tables 1 and 2).

Myofibrillar protein catabolic rate was found to be highly significantly raised in Duchenne muscular dystrophy (Table 1). In Becker muscular dystrophy the elevation was only significant at the $10 \%$ level (Table 2). It was also increased in a severe active case of motor neurone disease, and in cases of polymyositis and thyrotoxic myopathy (Table 1). It was normal in scapuloperoneal and limb girdle dystrophy, dystrophia myotonica, extrapyramidal disease, the Lesch-Nyhan syndrome, and multiple sclerosis, but was decreased in hypothyroid myopathy (Tables 1 and 2).

\section{Discussion}

The amino-acid 3-methylhistidine is formed by the post-translational methylation of specific histidine residues in the peptide chains of actin in all muscles and myosin in white muscle fibres (Asatoor and Armstrong, 1967; Johnson et al., 1967; Huszar and Elzinga, 1972; Pollard and Weihing, 1974). Haverberg et al. (1975) have demonstrated that over $90 \%$ of protein-bound 3methylhistidine is contained in the actin and myosin of rat skeletal muscle. However, Nishizawa et al. (1977) have shown that the non-muscle sources of 3-methylhistidine may contribute disproportionately to the total amount excreted because of their faster turnover. When muscle protein is degraded, the 3-methylhistidine is released, but it does not participate in amino-acid reutilisation, and is excreted unmetabolised (Young et al., 1972; Long et al., 1975). In human urine all the 3-methylhistidine is present as such, whereas in the rat a proportion is excreted as the $\mathrm{N}$-acetyl derivative (Young et al., 1972; Long et al., 1975). Thus the excretion of 3-methylhistidine in the urine has been taken as an estimate of muscle myofibrillar protein catabolism (Figure).

In order to calculate the amount of myofibrillar protein degraded daily in human subjects, it is necessary to know the concentration of proteinbound 3-methylhistidine in skeletal muscle. Previous estimates of myofibrillar protein catabolism in man have used the figure of $1.6 \mu$ moles $/ g$ of

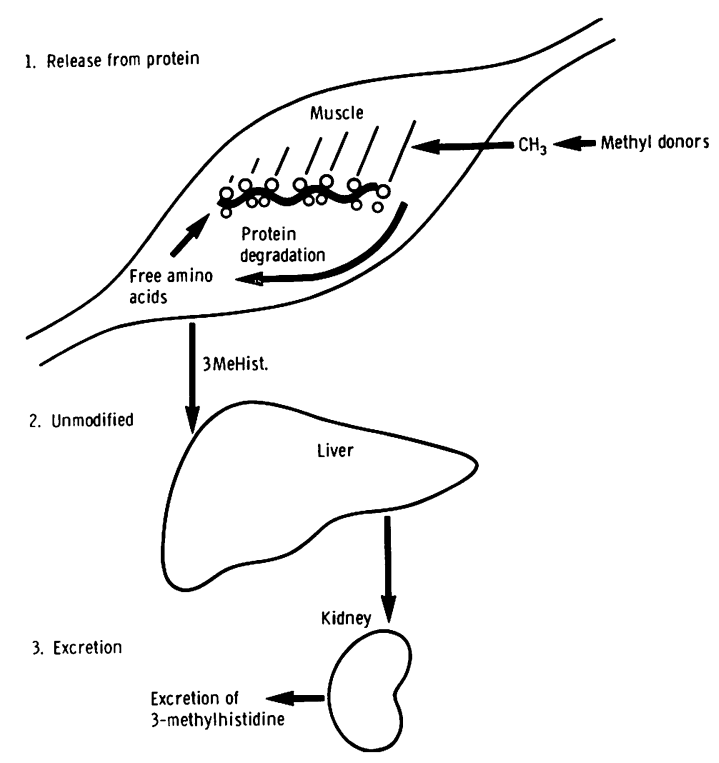

Figure 3-Methylhistidine excretion as a marker of muscle myofibrillar protein catabolism in man. 
mixed protein reported by Asatoor and Armstrong (1967) for the gastrocnemius muscle of one adult subject. Bilmazes et al. (1978) have recently reported a figure of 3.2 in infants and $4.2 \mu$ moles/g of mixed muscle protein in adults. These measurements were made on psoas muscle from nine infants, and four psoas, two latissimus dorsi, and one intercostal muscle in adults. It is important to state the muscle on which the determination was made, since differences in the percentages of type 1 to type 2 muscle fibres may account for the variation in 3-methylhistidine content of different muscles (Johnson et al., 1967; Trayer et al., 1968; Kuehl and Adelstein, 1970). The lower values for 3-methylhistidine content of infant as opposed to adult skeletal muscle may be due to the fact that fetal muscle contains less myofibrillar protein (Dickerson and Widdowson, 1960), and fetal white muscle fibres are not methylated (Trayer et al., 1968; Kuehl and Adelstein, 1970). It is assumed that the situation in the infant would be intermediate between the fetal and adult. We have taken the adult figure of $4.2 \mu$ moles/g of mixed muscle protein to represent the 3-methylhistidine content of muscle in the present study to calculate myofibrillar protein catabolism, since this approximates to that calculated by Wannemacher et al. (1975) for adult skeletal muscle, and by several observers for a variety of animal species (Bilmazes et al., 1978).

A number of assumptions are made in estimating myofibrillar protein turnover rates from 3methylhistidine excretion in human subjects. The first is that the 3-methylhistidine content of the different muscles of the body is reasonably constant. In a limited selection of muscles, Bilmazes et al. (1978) have shown this to be correct, with a range of 3.7 to $4.6 \mu \mathrm{moles} / \mathrm{g}$ of mixed muscle protein. Further studies on a much wider selection of muscles, however, are required to substantiate this point. There are no reports of the 3-methylhistidine content of diseased muscle, and it is, therefore, assumed that it remains unaltered in the present study in order to calculate myofibrillar protein catabolism. Should the vastus lateralis muscle 3-methylhistidine content prove to be representative of the mean concentration in the body's skeletal muscle, in both health and disease, future studies could use a figure obtained from the individual subject by percutaneous needle biopsy of muscle. Repeated biopsies would be possible because this technique is relatively atraumatic, and leaves a minimal residual scar (Edwards, 1971; McKeran et al., 1975).

Further, it is assumed in estimating myofibrillar protein catabolism from 3-methylhistidine excre- tion that creatinine excretion is an index of muscle mass (with $1.0 \mathrm{~g}$ excreted per day, equivalent to $20 \mathrm{~kg}$ of muscle) in both normal subjects and patients with neuromuscular disease. Lean body mass as determined by ${ }^{40} \mathrm{~K}$ radioactivity counting is highly correlated with urinary creatinine excretion $(r=0.988)$, and technical errors can be reduced by using three consecutive collections of urine as in the present study (Forbes and Bruining, 1976). Similar studies relating ${ }^{40} \mathrm{~K}$ counting to creatinine excretion are required in a wide variety of neuromuscular diseases to validate the conversion of creatinine excretion to muscle mass. Ryan et al. (1957), in a study of oxygen consumption and creatinine excretion in healthy and wasted men, demonstrated that creatinine excretion is a measure of lean body mass in muscle disease in a limited range of neuromuscular disease. The values for muscle mass obtained in the present study are generally in accord with our clinical evaluation of their lean body mass (Tables 1 and 2)

For the purposes of estimating myofibrillar protein catabolism from 3-methylhistidine excretion, it is assumed that all striated muscle myofibrillar protein is catabolised at a similar rate. There is no direct evidence to suggest that this is not the case in man, although there is ample experimental evidence to suggest that muscle proteins are catabolised at different rates according to their molecular species. Animal studies have shown that fractional protein synthetic rates for different skeletal muscles are approximately equal, although cardiac muscle has almost twice the rate of voluntary striated muscle (Buttery et al., 1975). Halliday and McKeran (1975) demonstrated that muscle sarcoplasmic protein synthetic rate was approximately twice that of myofibrillar protein in man. Clearly the situation with regard to rates of synthesis of different muscle proteins may be more complex than their rates of catabolism. Animal evidence is accumulating which suggests that muscle protein mass is regulated primarily through alterations in the rate of protein synthesis (Millward et al., 1976). McKeran et al. (1978) recently compared the rate of synthesis of human myofibrillar protein with the rate of catabolism derived from 3-methylhistidine excretion in the same subjects. The figure of $1.61 \mu$ moles $/ g$ of mixed muscle protein was used to calculate the rate of myofibrillar protein catabolism in that study. Using the value for 3-methylhistidine content of mixed muscle proteins provided by Bilmazes et al. (1978), a figure of 111 days from 3-methylhistidine and 68 days from continuous infusion of $\left({ }^{15} \mathrm{~N}\right)$ lysine was obtained for muscle 
myofibrillar protein turnover derived from the two methods. These values derived from two completely different methods provided estimates of myofibrillar protein turnover within the same order of magnitude. Final validation of the value of 3-methylhistidine excretion as a marker of muscle myofibrillar protein catabolism will require comparisons of muscle protein synthetic rates with directly measured catabolic rates in animals.

In the present investigation, the importance of using control subjects on a similar diet to the patients under study was emphasised by the fact that estimates of myofibrillar protein turnover on a normal diet were higher than those on a creatine-free diet, reflecting the dietary meat contribution to 3-methylhistidine excretion. We have previously established that three complete days should have elapsed on a creatine-free diet before collections of urine are used to estimate myofibrilla protein turnover, since it takes that length of time to clear the dietary contribution of this amino-acid from the body (McKeran et al., 1978).

We have previously reported the marked increase in myofibrillar protein catabolic rate in Duchenne muscular dystrophy when expressed as the percentage turnover of total muscle myofibrillar protein, thus taking account of the reduced muscle mass (McKeran et al., 1977). This observation together with decreased non-collagen protein synthetic rate in vitro in muscle from patients with Duchenne muscular dystrophy (Ionasescu, 1975) was taken to reflect progressive muscle cell death with increased muscle protein catabolism resulting in leakage of soluble enzymes into the plasma. A fundamental abnormality of the assembly of contractile muscle protein or the regulation of its rate of metabolism could not, however, be discounted completely as a possible explanation for the observed increase in rate of catabolism of myofibrillar protein. Increased activities of muscle lysosomal proteinase in Duchenne muscular dystrophy (Kar and Pearson, 1972) may cause or merely reflect the rapid breakdown of muscle proteins. McGowan et al. (1976) have recently described improvement in the growth of dystrophic chicken muscle in tissue culture when microbial antiproteinases were added to inhibit the activity of lysosomal proteinases. Enomoto and Bradley (1978) were unable to demonstrate any improvement in murine dystrophy when sodium aurothiomalate was given as an antiproteinase. This observation could be explained if the increased rate of catabolism of muscle proteins was secondary to some other fundamental defect of the cell as is now con- sidered likely. Other antiproteinases should be tested on animal models before it is concluded that this approach to treatment is likely to be fruitless.

In the present study, myofibrillar protein turnover rates were significantly raised in patients with Duchenne type and to a much lesser extent Becker type muscular dystrophy, motor neurone disease, polymyositis, and thyrotoxic myopathy (Tables 1 and 2). Normal values were encountered in scapuloperoneal and limb girdle dystrophy, dystrophia myotonica, extrapyramidal disease, and multiple sclerosis. In hypothyroid myopathy a decreased rate of myofibrillar protein catabolism was found. Numerous studies have established that thyroid hormone is a stimulator of muscle protein synthesis (Sokoloff et al., 1968) and our observation of decreased myofibrillar protein catabolism in hypothyroid myopathy is compatible with these conclusions. The extent of the increase in myofibrillar protein catabolism demonstrated in the different categories of neuromuscular disease in the present study was in general agreement with the rate of decrease of muscle mass. Myofibrillar protein catabolism provides a useful index in assessing the extent of muscle cell death in the muscular dystrophies and polymyositis, and dysfunction in thyrotoxic myopathy. Its dissociation from the extent of the rise of plasma CPK is notable in the case of thyrotoxic myopathy, where CPK levels are often normal or decreased. Further studies are required in polymyositis and the endocrine myopathies to establish whether the changes in myofibrillar protein catabolism during treatment accurately reflect the clinical improvement in muscle weakness. The increased intra-subject variations and dietary contribution to 3-methylhistidine excretion shown in the present study suggests that future controlled metabolic studies should be carried out on subjects on a creatine-free diet.

\section{References}

Asatoor, A. M., and Armstrong, M. D. (1967). 3Methylhistidine, a component of actin. Biochemical and Biophysical Research Communications, 26, 168174.

Bilmazes, C., Uavy, R., Haverberg, L. N., Munro, H., and Young, V. R. (1978). Muscle protein breakdown rates in humans based on $\mathrm{N}$-methylhistidine (3methylhistidine) content of mixed proteins in skeletal muscle and urinary output of $\mathrm{N}$-Methylhistidine. Metabolism, 27, 525-530.

Buttery, P. J., Beckerton, A., Mitchell, R. M., Davies, K., and Annison, E. F. (1975). The turnover rate of muscle and liver protein in sheep. Proceedings of the Nutrition Society, 34, 91A-92A.

Dickerson, J. W. T., and Widdowson, E. M. (1960). 
Chemical changes in skeletal muscle with development. Biochemical Journal, 74, 247-257.

Edwards, K. D. G., and Whyte, H. M. (1958). The measurement of creatinine in plasma and urine. Australian Journal of Experimental Biology and Medical Science, 36, 383-394.

Edwards, R. H. T. (1971). Percutaneous needle-biopsy of skeletal muscle in diagnosis and research. Lancet, 2, 593-596.

Enomoto, A., and Bradley, W. G. (1978). Therapeutic trials in muscular dystrophy. 1 . Gold in murine dystrophy. Journal of Neurology, Neurosurgery, and Psychiatry, 41, $404-407$.

Forbes, G. B., and Bruining, G. J. (1976). Urinary creatinine excretion and lean body mass. American Journal of Clinical Nutrition, 29, 1359-1366.

Graystone, J. E. (1968). Creatinine excretion during growth. In Human Growth, p. 192. Edited by D. B. Cheek. Lea and Febiger: Philadelphia.

Halliday, D., and McKeran, R. O. (1975). Measurement of muscle protein synthetic rate from serial muscle biopsies and total body protein turnover in man from continuous intravenous infusion of $\mathrm{L}-\left(\alpha^{-15} \mathrm{~N}\right)$ lysine. Clinical Science and Molecular Medicine, 49, 581-590.

Haverberg, L. N., Omstedt, P. T., Munro, H. N., and Young, V. R. (1975). $\mathrm{N}^{\mathrm{r}}$-methylhistidine content of mixed proteins in various tissues. Biochimica et Biophysica Acta, 405, 67-71.

Huszar, G., and Elzinga, M. (1972). Homologous methylated and non-methylated histidine peptides in skeletal and cardiac myosins. Journal of Biological Chemistry, 247, 745-753.

Ionasescu, V. (1975). Distinction between Duchenne and other muscular dystrophies by ribosomal protein synthesis. Journal of Medical Genetics, 12, 49-54.

Johnson, P., Harris, C. I., and Perry, S. V. (1967). 3-Methylhistidine in actin and other muscle proteins. Biochemical Journal, 105, 361-370.

Kar, N. C., and Pearson, C. M. (1972). Acid, neutral and alkaline cathepsins in normal and diseased muscle. Enzyme, 13, 188-196.

Kuehl, W. M., and Adelstein, R. S. (1970). The absence of 3-methylhistidine in red, cardiac and fetal myosins. Biochemical and Biophysical Research Communications, 39, 956-964.

Long, C. L., Haverberg, L. N., Kinney, J. M., Young, V. R., Munro, H. N., and Geiger, J. W. (1975). Metabolism of 3-methylhistidine in man. Metabolism, 24, 929-935.

McGowan, E. B., Shafiq, S. A., and Stracher, A. (1976). Delayed degeneration of dystrophic and normal muscle cell culture heated with pepstatin, leupeptin and antipain. Experimental Neurology, 50, $437-442$.
McKeran, R. O., Slavin, G., Andrews, T. M., Ward, P., and Mair, W. G. P. (1975). Muscle fibre type changes in hypothyroid myopathy. Journal of Clinical Pathology, 28, 659-663.

McKeran, R. O., Halliday, D., and Purkiss, P. (1977). Increased myofibrillar protein catabolism in Duchenne muscular dystrophy measured by 3methylhistidine excretion in the urine. Journal of Neurology, Neurosurgery, and Psychiatry, 40, 979981.

McKeran, R. O., Halliday, D., and Purkiss, P. (1978). Comparison of human myofibrillar protein catabolic rate derived from 3-methylhistidine excretion with synthetic rate from muscle biopsies during $L\left(\alpha{ }^{15} \mathrm{~N}\right)$ lysine infusion. Clinical Science and Molecular Medicine, 54, 471-475.

McKeran, R. O., Slavin, G., Ward, P., Paul, E., and Mair, W. G. P. (1979). Hypothyroid myopathy. A clinical and pathological study. In press.

Millward, D. J., Garlick, P. J., Nnanyelugo, D. O., and Waterlow, J. C. (1976). The relative importance of muscle protein synthesis and breakdown in the regulation of muscle mass. Biochemical Journal, 156, $185-188$.

Nishizawa, N., Noguchi, T., Hareyama, S., and Funabiki, R. (1977). Fractional flux rates of Nmethylhistidine in skin and gastrointestine: the contribution of these tissues to urinary excretion of $\mathrm{N}$-methylhistidine in the rat. British Journal of Nutrition, 38, 149-151.

Pollard, T. D., and Weihing, R. R. (1974). Actin and myosin and cell movement. CRC Critical Review of Biochemistry, 2, 1-65.

Ryan, R. J., Williams, J. D., Ansell, B. M., and Bernstein, L. M. (1957). The relationship of body composition to oxygen consumption and creatinine excretion in healthy and wasted men. Metabolism, 6, 365-377.

Sokoloff, L., Roberts, P. A., Januska, M. M., and Kline, J. E. (1968). Mechanisms of stimulation of protein synthesis by thyroid hormones in vivo. Biochemistry, 60, 652-659.

Trayer, I. P., Harris, C. I., and Perry, S. V. (1968). Methylhistidine and adult and fetal forms of skeletal muscle myosin. Nature, 217, 452-453.

Wannemacher, R. W., Dinterman, R. E., Pekarek, R. S., Bartelloni, P. J., and Beisel, W. R. (1975). Urinary amino acid excretion during experimentally induced sandfly fever in man. American Journal of Clinical Nutrition, 28, 110-118.

Young, V. R., Alexis, S. D., Baliga, B. S., Munro, H. N., and Muecke, W. (1972). Metabolism of administered 3-methylhistidine. Lack of muscle $t$ (RNA) charging and quantitative excretion as 3methylhistidine and its $\mathrm{N}$-acetyl derivative. Journal of Biological Chemistry, 247, 3592-3600. 